\title{
Populus resequencing: towards genome-wide association studies
}

\author{
Gerald Tuskan ${ }^{1 *}$, Gancho Slavov², Steve DiFazio², Wellington Muchero ${ }^{1}$, Ranjan Pryia', Wendy Schackwitz ${ }^{3}$, \\ Joel Martin ${ }^{3}$, Daniel Rokhsar ${ }^{3}$, Robert Sykes ${ }^{4}$, Mark Davis ${ }^{4}$, Michael Studer ${ }^{5}$, Charles Wyman ${ }^{5}$ \\ From IUFRO Tree Biotechnology Conference 2011: From Genomes to Integration and Delivery \\ Arraial d'Ajuda, Bahia, Brazil. 26 June - 2 July 2011
}

Genome-wide association studies (GWAS) have been used to identify regions of the genome related to various phenotypes in humans, corn, rice and cattle. Successful application of this approach to bioenergy crops such as Populus requires 1) an appropriate mapping population, 2 ) high-quality phenotypic data and 3) informative genotypic data. With the goal of reducing the recalcitrance of lignocellulosic biomass for economic production of biofuels and understanding basic mechanisms of cell wall formation in Populus we established 4 clonally replicated common gardens experiments each with 1100 native $P$. trichocarpa genotypes collected from along the northwest coast of the U.S. and Canada. A highthroughput phenotyping pipeline was developed to measure cell wall chemistry, pretreatment response and enzymatic sugar release. Initially 18 genotypes were resequenced to an average 30X depth in order to design a SNP array to test for statistical association using MMAX and PCA methods of testing among ca. 2500 candidate genes. Genetic structure and linkage disequilibrium (LD) was assessed using SSR and SNP markers. Outlying genotypes were excluded from the analyses and estimates of LD were used to design the bead array. Candidate genes were selected based on QTL intervals, expression profiling within developing xylem and expert opinion. MMAX and PCA results revealed similar significant associations for all measured phenotypes and several SNPs within the candidate gene set explain a relatively high degree of the phenotypic variance. As a result, resequencing has continued in order to conduct GWAS in Populus; the complete set of 1100 genotypes will be complete in 2012 .

\footnotetext{
*Correspondence: gtk@ornl.gov

'Oak Ridge National Laboratory, USA

Full list of author information is available at the end of the article
}

\section{Author details}

${ }^{1}$ Oak Ridge National Laboratory, USA. ${ }^{2}$ West Virginia University, USA. ${ }^{3}$ Joint Genome Institute, USA. ${ }^{4}$ National Renewable Energy Laboratory, USA.

${ }^{5}$ Univeresity of California Riverside, USA.

Published: 13 September 2011

\section{doi:10.1186/1753-6561-5-S7-I21}

Cite this article as: Tuskan et al:: Populus resequencing: towards genome-wide association studies. BMC Proceedings 2011 5(Suppl 7):121.

Submit your next manuscript to BioMed Central and take full advantage of:

- Convenient online submission

- Thorough peer review

- No space constraints or color figure charges

- Immediate publication on acceptance

- Inclusion in PubMed, CAS, Scopus and Google Scholar

- Research which is freely available for redistribution 